\title{
Orientalism and intelligence analysis: deconstructing Anglo-American notions of the 'Arab'
}

Article

Accepted Version

Rezk, D. (2016) Orientalism and intelligence analysis: deconstructing Anglo-American notions of the 'Arab'. Intelligence and National Security, 31 (2). pp. 224-245. ISSN 1743-9019 doi: https://doi.org/10.1080/02684527.2014.949077 Available at https://centaur.reading.ac.uk/57747/

It is advisable to refer to the publisher's version if you intend to cite from the work. See Guidance on citing.

Published version at: http://dx.doi.org/10.1080/02684527.2014.949077

To link to this article DOI: http://dx.doi.org/10.1080/02684527.2014.949077

Publisher: Taylor \& Francis

All outputs in CentAUR are protected by Intellectual Property Rights law, including copyright law. Copyright and IPR is retained by the creators or other copyright holders. Terms and conditions for use of this material are defined in the End User Agreement.

$\underline{\text { www.reading.ac.uk/centaur }}$ 
Central Archive at the University of Reading

Reading's research outputs online 


\title{
Orientalism and Intelligence Analysis: Deconstructing Anglo-American notions of the 'Arab'
}

\begin{abstract}
Despite revived notions of a 'cultural divide' between East and West, Edward's Said's 'Orientalism' has received little attention from scholars of intelligence and diplomacy. This article brings to light for the first time a number of recently declassified documents of a different nature to usual assessments produced by AngloAmerican analytic bodies: those focussed primarily on the issue of 'national character.' Using and critiquing Said's thesis of Western 'Orientalism' it reveals some critical and enduring conceptualisations articulated by the diplomatic and intelligence community about Arab culture such as the role of Islam, rhetoric, political motivation and notions of 'honour'. Such a critical approach demonstrates how diplomatic and intelligence history can also be a history of culture, ideas and institutional mentalité.
\end{abstract}

From the Iranian revolution to the 'Arab Spring', the West has been consistently accused of misunderstanding and misconceiving the culture and politics of the Middle East. Samuel Huntingdon's controversial 'Clash of Civilisations' thesis revived the arguments of Orientalists such as Bernard Lewis that the roots of this failure originate in a 'cultural divide' between East and West. The intelligence community have born the brunt of such criticism, yet little historical scholarship has explored how Arab culture has been conceived by the world's most important and powerful producers of 'knowledge' in recent history.

This exploration calls for a novel and interdisciplinary approach to intelligence scholarship, in a quest to reveal both the spoken and the unspoken in the historical record. James Joll's account of the origins of the First World War marked one of the earliest contributions to an enduring debate within the academic world as to the role of 'unspoken assumptions' in our study of the past. ${ }^{1}$ The 'New Cultural History' put 'mindset' at the forefront of the historian's intellectual agenda. ${ }^{2}$ We have learned that the past is another country; that its participants hold a mentalité fundamentally different to ours that must be appreciated, reconstructed, even deconstructed; and that detailed analysis of the text plays a central role in decoding the unspoken.

\footnotetext{
${ }^{1}$ James Joll, Origins of the First World War (London: Longman, 1984).

${ }^{2}$ Lynn Hunt, The New Cultural History (Berkeley: University of California Press, 1989).
} 
Edward Said's seminal 1978 work on 'Orientalism' was one of the most controversial offshoots of this new interdisciplinary approach. His sub-textual analysis of the 'unspoken' in European literary depictions of the Orient argued that negative Western stereotypes of the Middle East were created by, and provided justification for, a colonial system of political domination based on the West's demonstrable superiority to the Middle East. ${ }^{3}$ Yet as Matt Connelly has observed, 'post colonial scholars today catalogue the cultures of empire in novels and travel writing, museums and expositions, paintings and postcards - everywhere it seems, but the archives and personal papers of European and U.S. policy makers. ${ }^{4}$ Similarly Andrew Rotter notes that, 'Said's interest in the history of U.S. foreign policy has apparently not been reciprocated.' In 2001 Rotter estimated that of approximately 30 recent books on U.S.-Mideast relations, only three referred to Orientalism. ${ }^{5}$

It should not be surprising then that Said's influence and the 'cultural turn' of which he was a controversial part, has yet to make a significant and visible historiographical dent in the more nascent and specialised 'missing dimension' of intelligence history. ${ }^{6}$ Whilst scholars of intellectual or cultural history search for the stated and unstated assumptions of a 'Great Text', or the webs of signification that underlie a particular discourse or ritual, what of the ideas and assumptions underlying the many 'great texts' used to inform policy-makers? Deconstructing the secret mutterings of officials tasked with understanding the region, we can use political and

\footnotetext{
${ }^{3}$ Edward Said, Orientalism (London: Penguin, 2003).

${ }^{4}$ Matt Connelly, cited in Peter Jackson, 'Pierre Bordieu, the 'Cultural Turn' and International History' in Review of International Studies, Vol. 34, No. 1 (2008), pp.155-181.

${ }^{5}$ Andrew J. Rotter, 'Saidism Without Said: Orientalism and U.S. Diplomatic History' in American Historical Review, Vol. 105, No. 4 (2000), pp.1205-17.

${ }^{6}$ Reassuringly however, a slim catalogue of recent works suggest that even the most traditional realms of diplomatic, international and military history have been unable to resist the lure of the 'cultural' fever. Patrick Porter, Military Orientalism: Eastern War through Western Eyes (London: C. Hurst and Co. Ltd., 2009) presents a highly nuanced view of Western military encounters with 'the Other' demonstrating the complex ways in which culture can reflect, shape and be manipulated by warfare. James Vaughn, Unconquerable Minds: The Failure of American and British Propaganda in the Arab Middle East, 1945-1957 (London: Palgrave, 2005) stands as the first archival based account of British and American cultural propaganda in the Middle East during the Cold War. Frank Costigliola, 'Reading for Meaning: Theory, Language, and Metaphor" in M. Hogan, and T. G. Paterson (eds.), Explaining American Foreign Relations History (New York: Cambridge University Press, 2003) demonstrates the utility of literary theory to a deeper understanding American foreign policy. Christian Appy, Cold War Constructions: The Political Culture of United States Imperialism, 1945-1966 (Massachusetts: University of Massachusetts Press, 2000) provides a revealing insight into the political culture of American imperialism examining the discourses and unspoken assumptions that accompanied imperial adventures after World War II. Douglas Little, American Orientalism: The United States and the Middle East since 1945 (Chapel Hill: University of North Carolina Press, 2002) attempts to use Said's framework to examine post-war American foreign policy but with the exception of the first chapter fails to show how ideas about 'the Arab' affected or framed decision making.
} 
intelligence documents to reveal the innermost thinking of the elite producing 'knowledge' for policy-makers about the Arab 'Other.'

In addition to this theoretical approach, from an empirical perspective, this article brings to scholarly attention for the first time several recently declassified documents of a different nature to usual assessments produced by the British and U.S. diplomatic and intelligence analytic bodies: those focussed primarily on the issue of 'national character.' Unsurprisingly the declassified documents that deal in length with this are few (certainly their authors never imagined that these reflections on Arab culture would ever be available for public consumption). Nonetheless there are sufficient links between them (and repeated reference to their underlying assumptions in more routine diplomatic and intelligence analysis) to warrant a critical examination of the intellectual archive or 'library' that the Western political elite compiled about the Arab world. Analysts articulated notions of Arab culture such as the role of Islam, the use of rhetoric, political motivation and the primacy of 'honour' that continue to pervade Western perceptions of the region.

Considering the significance of Said's thesis to Anglo-American relations with the Middle East, why have diplomatic and intelligence historians failed so spectacularly to engage with 'Orientalism'? Critics rightly note Said's selective use of sources, his polemical rhetoric, his verbosity and a marked lack of historical analysis. ${ }^{7}$ The assertion that by writing about the Orient the author denies agency to, or indeed existence of, the Oriental subject reflects postmodernism at its most extreme and intellectually nihilistic. ${ }^{8}$ Said's suggestion that the West has a particular axe to grind against the Middle East is clearly disproved by Western stereotypes of other cultures (including of course other Westerners) and, rather, belies an inherent and universal human inclination to affirm the 'Self' in respect to the 'Other'. 9 There is no inherent 'hostility' in Western depictions of the Middle East; not all were designed to dominate and empower as Said claims. ${ }^{10}$ Indeed depictions of the 'Other' commonly reflect a more deeply rooted anxiety or doubt about the 'Self., 11

\footnotetext{
${ }^{7}$ For a detailed exploration of the intellectual debates sparked by Said see D. M. Varisco, Reading Orientalism: Said and the Unsaid (Seattle: University of Washington Press, 2007).

${ }^{8}$ Said, Orientalism, p.21: 'the written statement is a presence to the reader by virtue of its having excluded, displaced, made supererogatory any such real thing as "the Orient.",

${ }^{9}$ Fred Halliday, Islam and the Myth of Confrontation (London; New York: I.B. Tauris and Co. Ltd, 2003), p.210: 'The claim of a special European animosity towards Arabs, let alone Palestinians or Muslims does not bear historical comparison.'

${ }^{10}$ Said, Orientalism, p.45.

${ }^{11}$ Porter, Military Orientalism, p.19.
} 
By applying a critical approach to both Said's ideas and these controversial documents about the Arab national character, this article posits a set of more nuanced questions: What were the dominant ideas about the Arab 'Other' in this period; how did they evolve as the Western world came to terms with the end of empire and the 'winds of change' at home and abroad? What relation did their constructions of 'the Arab' have to 'reality' as perceived at the time and retrospectively? Juxtaposing the declassified material against interviews with surviving Western and Egyptian diplomats, the discussion that follows provides an insight into how a history of intelligence can also be a history of culture, ideas and mentalité.

\section{A NEW TERRAIN: THE CHALLENGE OF THE MIDDLE EAST}

The efforts of the post-war American intelligence community were directed against a clearly defined enemy within the polarised framework of the Cold War. Resources and expertise were allocated accordingly, despite the fact that the parameters of the Cold War were increasingly being redrawn beyond the European battleground. The arms deal between Czechoslovakia and Egypt in 1955 marked the beginning of Soviet penetration of the Middle East and signalled a new terrain on which the Cold War was to be fought. Both America and her Western allies sought to establish friendly relations with the Arab World. The intelligence community was thus forced to adapt their analytic capability and resources to understand a new cultural milieu, a task to which some maintain it is still struggling to rise. ${ }^{12}$

In fact, as early as 1959, the CIA's classified in-house journal produced a curious piece of intelligence analysis titled 'Intelligence Gathering in an Unlettered Land' that attempted to define the challenges the Middle East posed to the American intelligence community. ${ }^{13}$ The author Francis Hollyman outlined problems such as accessing 'open' and 'secret' sources in a closed society, the peculiarities of Arab communication, and the 'psycho-cultural' difficulties of recruiting assets in the Arab World. As the document progresses and the perceived challenges move from the

\footnotetext{
${ }^{12}$ Fawaz Gerges, America and Political Islam: Clash of Cultures or Clash of Interests (Cambridge: Cambridge University Press, 1999), p.9-10.

${ }^{13}$ Francis Hollyman, 'Intelligence Gathering in an Unlettered Land' in Studies in Intelligence, Vol. 3, No. 3 (1959), Freedom of Information Act Electronic Reading Room (hereafter FOIA Reading Room).
} 
practical to the 'psycho-cultural,' they become increasingly crude and stereotypical to the ears of the modern reader. As Said insists, it is difficult to dismiss the implicit assertions of inferiority in such works as they attempt to describe and explain the cultural behaviour of the Middle East. At the same time, this document provides historians with invaluable insight into the challenges the CIA perceived itself to face in the Arab world and the simultaneous if contradictory impulses of ethnocentrism and open-mindedness with which it made sense of this encounter with 'the Other.'

\section{PROBLEMS OF ACCESS}

Few American intelligence officers acquired access to the political elite in the Arab World. Britain's colonial background ensured a steady stream of Arabists with linguistic and cultural expertise in the region but it was only in the 1950's that Ivy League universities recognised a similar need. The American intelligence community therefore relied heavily upon 'open-source' material for its analysis of Middle Eastern political dynamics. CIA analyst Hollyman wrote, 'the official radio and press service, organised efficiently in recent years has become more effective in preventative control of thought rather than informational content.' 14 'Mirror-imaging' the role of the Middle Eastern press to its Western counterpart, Hollyman dismissed Arab newspapers and radio as mere propaganda rather than a source of information or 'facts'; the notion that this 'preventative control of thought' might also be an avenue of useful analysis by American intelligence was at this stage not considered.

The lack of 'open sources' in the form of media, published surveys, handbooks and statistics also restricted the numbers and quality of human sources 'with access to such knowledge.' This derived 'in part from meagre opportunities for education and in part from traditional restrictions on participation in political and public life.' This non-democratic distribution of political information in many ways paralleled the difficulties of intelligence collection in the Soviet Union, but it was in an unfamiliar social context. In addition to the realities typical of closed societies, such as 'the virtual absence of easy social contacts, the lack of suitable public meeting places, the staggering inadequacy of public communications, and the suspicions commonly

\footnotetext{
${ }^{14}$ Ibid.
} 
aroused among native residents by outsiders attempting to move freely among them,' covert operatives had a range of other practical difficulties to overcome. Hollyman sardonically observed that the 'religious requirements of Ramadan, the month of fasting, and of the annual hajj [sic] or pilgrimage to Mecca, tend to damp down any information collecting activities for considerable periods of time. ${ }^{, 15}$ Such practical features of political and social interaction within the Arab world exacerbated difficulties already inherent in the agent acquisition process.

\section{ARAB RHETORIC}

When a source was eventually recruited, his mode of communication was also difficult for the American agent to grasp. Hollyman's analysis presented some of the 'more subtle' cultural difficulties that the intelligence officer and analyst might confront in the Arab World. He observed, for example, that in Arab political culture 'an unusual degree of reliance is placed on the spoken word, the personal mission and the personal memory of the minister himself. ${ }^{16}$ The reliance on informal rhetoric as the primary conduit of political communication was, understandably, perceived as strange to a Western political culture fundamentally rooted in the written word and official documentation. The analysis noted that the principal danger of relying on oral communication was the Arab tendency to 'simplify and omit when he has to deal with complicated matters. ${ }^{17}$ Later studies by anthropologists such as Adda Bozeman would observe,

Writing fixes meaning that in speech tend to be fluid...stimulates precision and differentiation in both thought and expression, stresses coherence and consistency in the thinking process; guards against drifting from one plane of reflection, or one frame of reference, to another; and promotes detachment and objectivity by disengaging the mind from the immediate experience and directing it, instead, to the level of conceptualisation. ${ }^{18}$

\footnotetext{
${ }^{15}$ Ibid. Another practical problem Hollyman identified was the Arab sense of time: 'For him [the Arab], infinity stretches out ahead, contiguous and real. He seldom, perhaps never, feels the pressure of time. The concept of a fiscal year is wholly foreign to him, either as a measure of time or as a means of controlling expenditures. The notion of "production" of political information in certain quantities within a certain period would puzzle him. He does not have our sense of schedule, of a deadline, of a program. Nothing can be done to make him work at a set rate of speed, let alone hurry.'

${ }^{16}$ Ibid.

${ }^{17}$ Ibid.

${ }^{18}$ Adda Bozeman, Conflict in Africa: Concepts and Realities (Princeton: Princeton University Press, 1976), p.70: 'literacy thus invites to the mind a special kind of analytical observation: to be continually conscious of the multiple relationships between signs and sounds on the one hand, and the ideas and
} 
Bozeman's analysis is essentially a more sophisticated and well-articulated explanation of Hollyman's conclusion that oral communication tended to be less precise and, as he correctly ascertains, is considerably more prevalent in Arab political culture than in the Western world. American ambassador Hare reported a similar observation in dealing with Egyptian President Nasser:

This habit of Nasser's do business in top of head without record when coupled with obviously defective time sense may indicate that his disconcerting habit of rewriting history which usually interpreted as deliberated distortion, may in fact be due in part and at times at least to confused memory. Consequence is that getting story from horse's mouth in his case may well represent his firm recollection but still be historically defective. ${ }^{19}$

Ambassador Hare sympathetically reported that what seemed to Western policymakers to be 'deliberate distortion' could be better explained as the product of a political culture where there was a greater reliance on the spoken word, which in turn rendered inaccuracies more likely. Hare also made reference to the 'instinctive Arab aversion to legalistic engagements as contrasted with informal and unpublicised agreements which are quite congruous with their mental processes. ${ }^{20}$ One only needs to compare the archival records or libraries of any Arab country to those in the West to observe the relative importance of the written word in the latter of the two cultures.

The work of another anthropologist reviewed by the CIA in 1973 reinforced the notion of greater 'discursive freedom' prevalent in the Arab world. ${ }^{21}$ The issue of Arab rhetoric continues to be identified as an important and enduring challenge to the West. As one eminent American Arabist put it, 'In the Middle East, rhetoric obscures truth and it reflects different mindsets from those in other areas of the world. ${ }^{22} \mathrm{~A}$ British diplomat agreed that the observations on Arab rhetoric have 'continuing relevance' although he rightly qualified: 'they are also, in varying degrees, capable of being applied to almost any society. ${ }^{, 23}$ This is indeed the case and yet the enduring

\footnotetext{
objects they represent, on the other; to weigh every word and to verify the particular functions of the word in terms of the idea it is supposed to represent.'

${ }^{19}$ Telegram from Ambassador Hare in Cairo to State Department, 18 February 1958, Foreign Relations of the United States (hereafter FRUS) 1958-1960, Vol. XIII, No. 197.

${ }^{20}$ Telegram from Ambassador Hare in Cairo to State Department, 11 April 1958, FRUS 1958-1960, Vol. XIII, No. 204.

${ }^{21}$ Raphael Patai, The Arab Mind (New York: Charles Scribners and Sons, 1973). Patai's book was reviewed by Lloyd F. Jordan at the CIA's in house journal Studies in Intelligence (1974) https://www.cia.gov/library/center-for-the-study-of-intelligence/kentcsi/vol18no3/html/v18i3a06p_0001.htm [last accessed 30 September 2012]

${ }^{22}$ Richard Parker, Politics of Miscalculation in the Middle East (Bloomington: Indiana University Press, 1992), Introduction xii.

${ }^{23}$ Derek Plumbly, e-mail to author, 2 January 2009.
} 
and recurring reference to the issue of Arab rhetoric suggests that this was perceived to be a problem specific to Arab culture. This early CIA analysis (alongside others in the period) made it clear that Arab rhetoric frequently served a culturally specific function that required decoding.

\section{ARAB MOTIVATION}

If Arab 'rhetoric' demonstrated the 'Otherness' of Middle Eastern culture, the question of Arab 'motivation' proved even more obscure. The 1959 CIA analysis relayed an established imperial belief that the Arab suffered from a fundamental inability to understand and practice constructive politics.

Aside from wanting to be a proper Arab and a good Muslim, he [the potential source] has no strong aims or convictions. His experience is too little, his ignorance too great, to provide a foundation for opposition to Communist imperialism as his motive force. He has no strong sense of socio-political responsibility, no felt need for thinking, for making a political choice. The idea of subscribing to a positive ideological program or doctrine, except as it incorporates his immediate Arab interests, is beyond him. ${ }^{24}$

This idea of 'the Arab' as devoid of 'social conscience' is present in other intelligence documents that have recently been released by the CIA. A working draft dated 25 July 1952, entitled 'Psychological strategy plan for the Middle East' explained the instability of the region as a result of, in part, a 'lack of social consciousness or a sense of public responsibility on the part of almost all officials. ${ }^{, 25}$ Similarly the State Department's Office for Intelligence and Research (INR) argued that Soviet attempts to penetrate the Middle East would face the challenge of 'the opportunistic concern of the Arab with his own immediate self-interest, and his poor sense of discipline, self-sacrifice and security consciousness. ${ }^{26}$ There is a policy implication underlying this conclusion - an unspoken obligation on the part of the West to civilise the politics of the region since the Arabs cannot be relied upon to make the right political choices. This perhaps accounts for the reluctance of Western

\footnotetext{
${ }^{24}$ Hollyman, 'Intelligence Gathering in an Unlettered Land' in Studies in Intelligence (1959), FOIA reading room.

${ }^{25}$ Working Draft, 'Psychological Strategy Plan for the Middle East', 25 July 1952, CIA Records Search Tool (hereafter CREST), at the National Archives at College Park, College Park Maryland (hereafter NARA II).

${ }^{26}$ Intelligence report, 'Problems and Attitudes in the Arab world: their implications for U.S. Psychological strategy', 19 May 1952, State Department Intelligence and Research Reports (hereafter OSS/SDIRR), The Middle East 1950-1961, Microfilm, Reel 1, SOAS Library.
} 
powers to take Arab nationalism seriously, as intelligence insiders have intimated. ${ }^{27}$ It may also, among other factors, explain the penchant for covert action and military intervention that marked Western policy towards the Arab world in this period.

An analysis of the situation in the Arab world following the tripartite Suez invasion of Egypt explained: 'Our hesitancy at taking actions favourable to Middle East national aspirations has as its deepest motivations the suspicion that once national aspirations are "satisfied," it will not be in either our power or that of Middle East nations to prevent the forces released from degenerating into anarchy., 28 Similarly the Eisenhower doctrine was seen to have failed because of the 'Arab reluctance to be committed. ${ }^{, 29}$ References to 'emotion' in politics or the 'apathy' of the public were other symptoms of the political immaturity of the Arab. Hollyman goes on to illustrate his point with a specific example: 'At the height of the $1956 \mathrm{Suez}$ crisis he [the source] hoped for nothing more than an immediate end to the fighting; he could not comprehend the international forces at work and he was afraid. He respects force partly because it is simple and within his comprehension. ${ }^{30}$ What Said has described as the 'childish primitive' depiction is clearly discernible - the Arab is too politically young, inexperienced and ignorant to feel bound to a body politic in which he has a voice, an opinion, or even a thought. ${ }^{31}$

Hollyman explained,

It is not uncommon to find that a relatively well educated [BLANK] who occupies an important place in commerce or government cannot read a map, and he may not even be aware that the world is not flat! With this shocking elementary ignorance he cannot begin to comprehend or care about more complex or subtle things like the meaning of the Iron curtain or problems springing from Communist imperialism. ${ }^{32}$

In the eyes of the CIA, the elite of Arab society clearly did not measure up to their Western counterparts. The consequence (and indeed, ultimate demonstration) of this 'shocking elementary ignorance' was that these targets were not able to understand or

\footnotetext{
${ }^{27}$ Percy Cradock, Know Your Enemy: How the Joint Intelligence Committee saw the World (London: J. Murray, 2002) p.111.

${ }^{28}$ Memorandum for the DCI, 'Dangers in the Suez Situation', 13 March 1957, CREST, NARA II.

${ }^{29}$ Salim Yacub, Containing Arab Nationalism: the Eisenhower Doctrine and the Middle East (North Carolina: University of North Carolina Press, 2004), p.12.

${ }^{30}$ Hollyman, 'Intelligence Gathering in an Unlettered Land' in Studies in Intelligence (1959), FOIA reading room.

${ }^{31}$ Said, Orientalism, p.247.

${ }^{32}$ For a particularly sexualised description of 'the Libyan,' see, T. Leidesdorf, 'The Libyan as agent' in Studies in Intelligence Vol. 7, No. 1 (1963), FOIA Reading Room: 'Befriending a Libyan is much like acquiring a mistress: once the cautious, tentative, defensive sparring is over, the relationship grows progressively deeper, broader, more involving, more consuming, more demanding.'
} 
care about the preeminent threat from the Soviet Union. The difficulty of recruiting Arab agents to work with Americans against 'the Communist threat' surfaces several times in the text, demonstrating both the priorities of the American intelligence community operating in the Arab World and the conclusions that they drew from the difficulties they faced: the typical Arab recruit was too simple, ignorant or apathetic to appreciate the ominous danger of Soviet designs. This accusation was also frequently directed at Arab nationalist leaders such as Egyptian president Nasser and his Iraqi counterpart Abdul Karim Qasim who sought aid from the Soviet Union. ${ }^{33}$

According to Hollyman, the Arab did 'not like to generalise about the world, because all he knows is his home, the marketplace, the desert and the edge of the sea...His aims and desires are very simple ones and he does not want to change them...He is essentially gentle, not belligerent. ${ }^{34}$ One does not have to go to the extreme of Said's arguably over-gendered analysis of Orientalist studies to observe the feminine adjectives associated with the Arab - 'simple, gentle, non-belligerent.' Note also the romantic associations of the Near East - the desert, the sea, the marketplace, in spite of the fact that most of the natives with which the American intelligence officer interacted would have been in a predominantly urban context. The undertones of a traditionalist and primitive Near East, unwilling to modernise and move forward is clearly discernible. Hollyman concluded that 'the cultural differences that wall off Westerners go down to the very roots of motivation and thinking. ${ }^{35}$

\section{BRITISH CONCEPTUALISATIONS OF THE ARAB WORLD}

Diplomat and former head of the JIC, Sir Patrick Wright, expressed incredulity that such an assessment had escaped the attention of the State Department or the British analytical bodies. They 'would have been howled down,' he claimed in correspondence with the author. ${ }^{36}$ Yet in a curious coincidence the British Steering Committee also produced several reports in 1959 that endorsed some of these

\footnotetext{
33

${ }^{34}$ Hollyman, 'Intelligence Gathering in an Unlettered Land' in Studies in Intelligence (1959), FOIA reading room.

${ }^{35}$ Ibid. He qualified that these 'subtler peculiarities... would probably not be very apparent if we ourselves did not have definite expectations of a behaviour [sic] which fits our requirements in those whom we want to use as sources.'

${ }^{36}$ Patrick Wright, e-mail to the author, 8 December 2008.
} 
assertions in an examination of the social and political forces in the Arab world. It is likely that upheavals in Syria and Iraq (particularly the latter) may have prompted this British reflection on Arab culture.

The influence of the Iraqi revolution in the British reports is implied by the reference to the 'violence' of the Arab mob, in notable contrast to the 'essentially gentle' Arab depicted in the CIA piece. The Steering Committee observed that

the behaviour of Middle Eastern crowds conforms to the pattern of crowd psychology everywhere; but as Arabs are less restrained and as standards of conduct in the Middle East are generally lower, education less effective and the unremedied social evils greater than in Western Europe, the Arab mob may act with more brutish violence than Europeans are now generally capable of.

The analysis even suggested that the inherent violence of the Arab world explained the political role of Middle Eastern armies since only the military possessed the ability to exert physical control over the Arab mob. ${ }^{37}$

British reports reinforced also the political apathy of the majority. The Committee agreed that despite the impact of improved education and communication, it is probable that the peasant...has as yet little awareness or comprehension of the world outside his village...thought he may at times be pertinacious, and even violent, in defence of his local interests, he has never been capable of associating for political ends.' Even the educated and professional were largely 'lacking in judgement and a sense of social responsibility.' 38

British analysis was however more attuned to the institutional reasons for this prevalent feature of Arab political culture. The nature of education in the Arab world, they explained, focussed on 'memorising and reproducing,' to the extent that students and officials were 'no longer capable of forming an original thought or an independent opinion, still less of applying their learning to the solution of practical problems.' Moreover they noted that the 'seeds of educational reform' were visible and capable of forming a "wide educated class able to play an intelligent and

\footnotetext{
37 FO Steering Committee Paper No. 13, 'Social and political forces in the Arab Middle East' 1959, FO 487/13. The paper qualified its conclusions at the start thus: 'A handicap in writing a paper of this kind is that little serious sociological research has been done on Middle Eastern countries. There is little evidence on which to base assumptions about the modes of thought of the new men who are coming to power in these countries or who may be influential in the future. Until this field has been more thoroughly explored, any conclusions are bound to be tentative.'

${ }^{38}$ Ibid.
} 
responsible part in public affairs' although the process of development was 'likely to be a long one. 39

The Committee's findings reinforced the State Department's frustration expressed some years earlier that the Arabs had imported Western ideas but proved unable to apply them. Arab ideas of 'democracy' were 'constantly confused with the social egalitarianism of Arab tradition.' The State Department analysis highlighted the problem of 'formal democratic institutions imposed on a society not prepared for them.' Intrinsic to Western democracy were values unfamiliar to the Arab world, including secularism, 'the free spirit of scientific enquiry, the right of the autonomous individual within a reasonable secure community, and the ability to see political processes in terms of institutions rather than personalities. ${ }^{40}$ The Committee noted that although politically active minorities 'resented the abuse of democracy by their opponents in power, they have behaved in the same way when they had the opportunity. ${ }^{41}$ As Vice President Omar Soleiman echoed in the 2012 Egyptian presidential elections, the Arab world was not ready for democracy. ${ }^{42}$

British analysis agreed also with the deceptive nature of rhetoric in Arab culture. 'The condition of the poor and oppressed inspires the intelligentsia to make political and xenophobic speeches rather than to do anything about it themselves.' But they noted, 'this is not necessarily hypocrisy. To an Arab, words tend to be ends in themselves, and he sees nothing essentially reprehensible in failing to practice what he preaches. ${ }^{43}$ The report wrote with derision (thinking no doubt of the regimes in the Levant): 'As with social welfare, so with civil liberties; though Arab radicalism passionately champions them in words, it does little practical work in defence of them. ${ }^{44}$ Like many of the assertions above, the gap between rhetoric and action

\footnotetext{
${ }^{39}$ Ibid: 'Unfortunately little is done in the home to correct the mischief done in the schools. The excessive indulgence shown in Arab families to male children, especially the first born, has a deplorable effect on the character of the young Arab, making him conceited, argumentative, resentful of criticism and scornful (or frightened) of manual work.'

${ }^{40}$ Intelligence Report, 'Problems and Attitudes in the Arab world: their implications for U.S. Psychological strategy’, 19 May 1952, OSS/SDIRR, The Middle East 1950-1961, Microfilm, Reel 1, SOAS Library.

${ }^{41}$ FO Steering Committee Paper No. 13, 'Social and political forces in the Arab Middle East', 1959, TNA, FO 487/13.

${ }^{42}$ Omar Soleiman cited in P. Martin, 'How will the Arab Spring reshape the Middle East?', 23 August 2012. http://m.theglobeandmail.com/news/world/how-will-the-arab-spring-reshape-the-middleeast/article1360507/?service=mobile [last accessed 30 September 2012]

${ }^{43}$ FO Steering Committee Paper No. 13, 'Social and political forces in the Arab Middle East', 1959, TNA, FO 487/13.

${ }^{44}$ Ibid.
} 
became a conventional wisdom within the intelligence community's analysis of the Middle East.

\section{THE ROLE OF ISLAM}

The Steering Committee also addressed a cultural specificity of the region which the CIA had not explored in its 1959 analysis: the role of Islam in the Arab world. The JIC had long warned for example that whilst 'the Moslem faith appears superficially to be an effective barrier to Communism we consider that its importance as a stabilising factor should not be over-rated.' They explained that the influence of Islam in the Middle East was 'largely negative, in that where the Moslem faith is strong society tends to remain static. On the other hand, where modern civilisation has broken into Moslem strongholds, e.g. through exploitation of oil resources, the Moslem faith seems powerless to prevent a rapid demoralisation in the face of materialism. ${ }^{45}$ Suffice to say that Islam was not regarded as a positive force, and indeed was posited against 'modern civilisation'.

An intelligence report by the State Department in 1952 had also established that Islam as a religious ideology was on the defensive. In the eyes of analysts it had failed to modernise and provide an institutional and philosophical basis for the social and political forces in the region. ${ }^{46}$ And yet despite its inertia, Islam was still perceived to play an important role on the Arab mindset.

The Steering Committee gave as an example the relationship between Islam and pan-Arab nationalism. Arab nationalist theory, they wrote, rejected 'the idea of a religious bond' substituting 'for Islamic solidarity a pride of race, which though it is explicit in the Koran and early Arab historians, seems in its modern form to owe more to Hitler than to Mohamed.' However the fundamental appeal of Arab unity could

\footnotetext{
45 JIC memorandum (54) 72, 'Political Developments in the Middle East and their impact on Western interests', 11 November 1954, TNA, CAB 158/18 [Empahsis added]

46 Intelligence Report, 'Problems and Attitudes in the Arab world: their implications for U.S. Psychological strategy', 19 May 1952, OSS/SDIRR The Middle East 1950-1961, Microfilm, Reel 1, SOAS Library: 'The people of the Near East are caught up in a dynamically scientific, technologically powerful and dangerously nationalist world. To this world they bring a religiously inspired way of life which, born in a static, pre-scientific, pre-national era, lacks the institutions and perhaps the philosophical premises through which to revitalise its traditions...Even now, a politically crucial minority is looking, if not always with adequate understanding, for modern methods which promise success quickly and with the least political dependence of those nations from which such methods are learned.'
} 
ultimately be explained through a reductive recourse to Islam. 'Unity, indeed, is the first attribute of the Deity in Islamic theology and the word has such powerful religious and emotional associations that it is perhaps difficult for any but a few philosophically trained Arabs to consider "unity" analytically and dispassionately in any context. ${ }^{47}$

In a baffling underestimation of the practical and psychological appeal of Arab unity, the Committee concluded that 'most uneducated Arab Moslems feel simply that God is one, therefore Oneness is right.' Analysts asserted that 'the influence of the teaching of Islam for nearly fourteen centuries on the mind, outlook and behaviour of the individual Arab is of fundamental importance.' Beyond the issue of unity, 'to Islam is due the Moslem Arab's conviction of superiority, his resentment of foreign guidance or control and hence the frustrating dilemma of recognising his technical dependence on foreigners, while rejecting their intervention in his affairs.' The report maintained that 'Islam will continue strong, as a habit of thought if not as a practised religion.' To an all-encompassing and xenophobic 'Islam' were attributed deeply rooted Arab frustrations towards Western colonial control and exploitation. ${ }^{48}$

The State Department analysis some years earlier had demonstrated some nuance to this depiction of a static and unproductive Islam. Analysts noted that it was 'the symbols' of Islam which would 'still, for some time to come, mold [sic] the language of acceptance and rejection and affect the motivations of those now in control.' There was an important qualification reserved for the elite in power: 'rarely,' the report suggested 'would Islam affect their decisions to a decisive degree.' If secular solutions failed to solve the region's 'basic intellectual and social crisis' it was possible that 'Islam or rather a perversion of it' would 'exercise a decisive influence on political decisions in the Near East. Then emotional rejection of all the West stands for may become the negative content of Islam, and a totalitarian nihilism the Near East's primary defence mechanism. ${ }^{49}$ The State Department's report certainly supports the notion that the West viewed the Islamic world with some trepidation.

\footnotetext{
${ }^{47}$ Annex 'Arab Nationalism: The Historical Background' to FO Steering Committee Paper No. 8, 'Arab nationalist and radical movements in Egypt, the Levant and Iraq', 1959, TNA, FO 487/13.

${ }^{48}$ FO Steering Committee Paper No. 8, 'Arab nationalist and radical movement in Egypt, Levant and Iraq', 1959, TNA, FO 487/13.

${ }^{49}$ Intelligence Report, 'Problems and Attitudes in the Arab world: their implications for U.S. Psychological strategy’, 19 May 1952, OSS/SDIRR, The Middle East 1950-1961, Microfilm, Reel 1, SOAS Library.
} 
Anglo-American analysis thus suggests two strains of thought about Islam: the first was that 'Islamic culture' acted upon the masses in the Arab world and contributed largely to the appeal of Arab unity, to resentment against the West, and effectively nurtured a 'habit of thought' in the region fundamentally opposed to Western culture and modern civilisation. The second took a less deterministic view, noting that the influence of Islamic culture was a dynamic rather than static force, altered for example by secular education. Moreover, those in power would instrumentalize Islamic symbols and language to justify and explain their ideology in a quest for legitimacy. The idea of a static, imposing 'Islam' thus existed alongside an Islam that was subject to interpretation and use by its believers.

\section{ARAB HONOUR}

In 1964, the CIA produced a second piece of national character analysis of the Arab world entitled "“Face" among the Arabs'. Its author Peter Naffsinger also explored the role of Islam in Arab political culture, confirming the inherent passivity of the religion suggested by the previous analysis. The central thesis of the piece was that the primary 'national characteristic' of the Arabs was the importance of 'face' or honour in society. According to Naffsinger this commitment to 'face', explained crucial differences between Western and Arab attitudes to personal responsibility, due to the nature of Islam. 'To the Arab, all is from Allah, and if Allah does all, the individual cannot be held responsible. ${ }^{50}$ One cannot help but recall Said's contention

\footnotetext{
50 Peter Naffsinger, “"Face” Among the Arabs' in Studies in Intelligence Vol. 8 (1964), FOIA Reading Room: 'By definition and by profession, Islam is the surrendering of the self to the will of Allah...All of Muslim theology conveys the feeling that God is so all pervading and at the same time so far above and removed from the individual that all human actions and their consequences are but the sequels of God's doing.' Christianity on the other hand emphasized the 'personal God within each man, who enforces an ideal of perfection in behaviour and in thought' leading in turn to 'a sense of personal guilt and obligation beyond self.' Islam, 'religion, social force, and almost complete way of life' advocated a 'supremely impersonal God, above and beyond rather than within a person' who 'impresses on the individual no requirement to accept guilt or personal responsibility for anything or to develop a conscience differentiating between intrinsic right and wrong.' He noted that attempts to chastise Arab trainees thus met with dismissive responses. 'The Arab is unwilling and unable to accept the idea that he should feel either sorry or responsible for his mistake. He dismisses both blame and censure with a casual "min allah" -- "It is from God." To the remonstrance that it had better not happen again he answers "inshallah," "If God wills it," with exasperating nonchalance. In agent work, where supervision cannot be so close, this indifference to personal responsibility and tendency to atomistic thinking will necessarily be even more troublesome.' Thus, 'Man is required to follow the teachings of the Koran and the Hadith and to perform his religious obligations' but in contrast to his Western,
} 
that Western assessments of the Arab 'Other' have been conceived primarily to assert the moral authority of the Self. The first paragraph of the analysis exemplifies Said's assertion:

George Washington, American children are told, having cut down his father's favourite cherry tree, showed his sterling character by confessing to the deed. An Arab hearing this story not only fails to see the moral beauty of such behaviour but wonders why anyone would ever compromise his integrity by admitting thus his guilt. As to Washington's explanation that "I cannot tell a lie," the Arab asks how a man could rise to the presidency if he were not suave enough to use a well-concocted falsehood as a tactic in emergency behaviour. $^{51}$

The analysis that follows proves how all too often, ideas of 'the Other' reflect idealised concepts of the West, particularly notions of the 'objective West' versus the 'subjective Arab.' Naffsinger's language is permeated by the discourse of Enlightenment associated with the American, demonstrated by his 'uncompromising willingness to face objective truth and fact.' The American is 'culturally obliged to reconcile his position and his person with truthfully interpreted reality' at 'all times and in all circumstances' whilst the Arab exists in a contrary cultural setting. He 'manifests his honour and integrity by making a public, outward impression of dignity derived from an ostensible lack of guilt. Even if facts and conditions speak to the contrary, the social veneer of non-guilt must be maintained evident and dominant if he is to achieve the socially demanded face.' Thus whilst American political culture demanded an honest engagement with the objective realities of 'truth' and 'fact' Arab culture bred merely a façade of dignity, based on the 'social veneer of non-guilt' that is demanded by a society which has 'no place or respect for one whose faults or errors come to public knowledge. ${ }^{52}$ The unspoken implication is surely that American identity and integrity, founded on objective truth and fact, is more 'authentic' or 'real' than that of his Arab counterpart, beneath which lies a plethora of 'faults and errors' that he is socially obliged to conceal. The analysis certainly substantiates the suggestion of scholars such as Fawaz Gerges that 'America considers itself a morally and politically superior society, a shining city on a hill, with a universal mission informed by a sense of exceptionalism. ${ }^{53}$

\footnotetext{
Christian counterparts he was 'not answerable to an inner God, a conscience.' As a result, 'instead of a sense of personal responsibility for his acts, the Arab has a deeply inculcated fear of outside forces; he realizes he must answer for his actions to society.'

${ }^{51}$ Ibid.

52 Ibid.

${ }^{53}$ Gerges, America and Political Islam, p.5. At the same time this self-veneration was not absolute. Naffsinger's analysis cited American sociologist Samia Hamady's account of an 'Arab who caught
} 
And yet perhaps the most important aspect of this analysis, and where it was a considerable improvement on its predecessor, was its attempts to explain cultural differences between the Arab world and the West in relativist terms. Naffsinger explained the cultural gap between the Arab and American's approach to 'logic' thus:

Facts and circumstances can combine in many different ways to reflect unfavourably upon any man, but the Arab cannot afford to allow accrued facts or logic to impute any flaw or guilt to him personally. In self-defence he must interpret the assembled facts subjectively, deny them outright, or reject as illogical any construction that leads to intimations of personal shortcomings. To the American, this defence is non-objective, a distortion of the truth, and therefore paradoxically destructive of integrity, unless he can take the Arab point of view and recognise personal face as having a higher value than fact or logic in the society.

Ignoring for a moment the historical detail that it was predominantly Muslim scholars who introduced the ideas of Aristotelian logic to the West, there is an important nuance to this by now familiar juxtaposition of the subjective, deluded Arab against the objective, enlightened American. The final sentence makes explicit that the Arab's behaviour only appears in this negative light 'to the American... Unless he can take the Arab point of view and recognise personal face as having a higher value than fact or logic in the society.' If the American is able to step out of his own shoes, look beyond his own values, his own perspective and culture, he will be able to see that the definition of integrity in the two cultures is fundamentally different. For the American it rests on a commitment to fact and objectivity; for the Arab it relies on a commitment to 'personal face' or honour in the eyes of his society. Naffsinger clarifies early on in the analysis: 'In our culturally determined scale of values the achieving of impersonal objectivity with regard to facts and truth is more important than preserving a man's dignity before the world at large.' He makes explicit reference to 'our culturally determined scale of values' as if to remind his readers that these American values are not universally shared. Thus 'Arab's untruths, half-truths,

another man in bed with his wife levelled a gun at them, but instead of shooting he offered to let the man off if he would keep the affair secret. The man promised and was let go. Later the Arab divorced his wife quietly, and the incident was considered closed. The double murder that might have been the outcome in Western cultures would have made newspaper headlines, a result diametrically opposed to the Arab's priority considerations.' The analysis suggested that 'the emotional distress which other husbands might have felt was for the Arab a problem of secondary importance; he could tell himself that Allah determines all and therefore not to trouble himself with the sequels of any acts.' Naffsinger concluded: 'This story illustrates well the principle that the Arab is the reverse of the Westerner in that he feels very strongly the force of public shame in loss of face but is able to slough off the feelings of personal inadequacy which would be acute in a Westerner.' Whilst much of the analysis stressed the inferior nature of Arab political and social behaviour this example could also be read as a critique of Western individualism. 
avoidance of reply or other ploys that jar Westerners do not spring from any perverse desire to deceive; they are facets of the need to maintain that personal dignity and face which in his system of values take precedence.' 54

Such efforts to maintain 'face' appeared

almost paranoiac by Western standards. Entertaining delusions of grandeur, claiming to be persecuted, magnifying faults in others than one wants to hide in oneself, calling constantly for resurgence of past greatness - all this is behaviour typical of paranoia, but it is manifested in every Arabic political newspaper and among individuals in day to day intercourse. It cannot be considered abnormal in the Arab cultural setting...The Westerner who, recognising in the Arab the personality traits which in Western culture signify paranoia or inferiority complex, is pleased with himself for being able to 'see through the Arab's attempts at deceit and trickery and his lies' shows his lack of appreciation of the face concept in the Arab culture. It is the Westerner who has learned always to allow the Arab a graceful way to save himself from the implications of guilt when difficulties arise who will make him a friend and avoid many frustrations and impasses in the relationship. ${ }^{55}$

The admission of relative definitions of 'normality' is notable. What is defined as paranoia in a Western cultural setting was recognised by analysts to be acceptable behaviour in Arab culture, a 'socially practical and accepted method' of 'refuting any outside attack on his [the Arab's] identity.' The Westerner imposing his definition of normality upon Arab behaviour was thus gently condemned of cultural ignorance. We see yet another (this time more constructive) policy recommendation implied: that only the Westerner who recognises the importance of 'face', and allows the Arab an avenue to maintain it, will succeed in political and social interactions with his Arab counterparts. ${ }^{56}$ Moreover analysts were now using the sort of open source material that they had dismissed some five years earlier as propaganda or 'control of thought,' to study what such thought entailed, how it was perceived by the West, and above all what it reflected about the mindset and different cultural values of the region.

Naffsinger gave the following example to demonstrate that the values esteemed highly in the West such as 'fact' and 'logic' were often subordinated in the Arab World to the pre-eminent cultural value of 'face' or honour:

In an oil company installation near the Persian Gulf, an American linguist in the training department, after drafting some exercises to be used in instructing American employees in spoken Arabic, gave them to three bilingual Saudi Arabs working for him to check for syntactic and orthographic correctness before publication. The drafts were all tacitly okayed, returned without change but after they had been published several glaring errors in

\footnotetext{
${ }^{54}$ Naffsinger, "Face” Among the Arabs' in Studies in Intelligence, Vol. 8 (1964), FOIA Reading Room [emphasis added].

${ }^{55}$ Ibid [emphasis added].

${ }^{56}$ This was a frequent recommendation made by Anglo-American diplomats in the Arab world to policy-makers in their dealings with Arab leaders.
} 
the work were discovered. Distressed, the linguist questioned the three Arabs who reluctantly explained to them that the inaccuracies had of course been obvious to them but they did not feel it would be right to point them out and thereby cause embarrassment to their boss and good friend! $!^{57}$

Whilst the Western counterpart might prioritise the objective accuracy of the work, this matter was 'of secondary importance to the Arabs.' Rather, it was understood that the Saudi Arabs 'believed in good faith that they had acted with honour as gentlemen in protecting the linguist's dignity above all other considerations.' Unlike the earlier CIA analysis of 1959, Arab behaviour is no longer dismissed as simple or ignorant, but rather subject to a different order of rationale. The author goes on to qualify, 'with this subjective processing the facts become what the Arab emotionally wants to believe is true. They can thus be made to mesh harmoniously with criteria which stand higher on the value scale because connected with the maintenance of face. ${ }^{, 58}$

Whilst validating earlier ideas about the passivity of Islam and the inferiority of Arab political culture, 'Face among the Arabs' also formalised an important idea upon which analysts came to rely. 'Honour' was naturally a value found in all parts of the world, but in the Arab world it was perceived to be more deeply rooted and thus likely to affect corollary beliefs and interpretations. A British diplomat recently reflected for example that the "passages on face/objectivity sound familiar in light of the denial with which many in the Arab world greeted 9/11. ${ }^{59}$ Most importantly however, the piece established that Western values could not be considered as universal and thus the analyst seeking to understand the Arab world in Western terms was likely to founder. Undoubtedly wider intellectual currents prevalent in the 1960s such as the rise of the social sciences, the civil rights movement and particularly the increasingly frustrating experience of Vietnam played a part in this increased self-reflexivity, as illustrated in the following piece.

\section{DECONSTRUCTING THE SELF}

In the 1974 winter edition of Studies in Intelligence, a third article entitled 'Reexamining our perceptions on Vietnam' addressed the problem of overcoming

\footnotetext{
${ }^{57}$ Naffsinger, “"Face” Among the Arabs' in Studies in Intelligence Vol. 8 (1964), FOIA Reading Room.

${ }^{58} \mathrm{Ibid}$

${ }^{59}$ Derek Plumbly, e-mail to author, 2 January 2009.
} 
cultural 'Otherness' in analysis. In an exploration of past assessments on Vietnam, the author Anthony Lewis argued that faulty Western analysis stemmed from insufficient cultural understanding and self-awareness. He wrote that analysts needed 'to overcome unconscious assumptions that our views and convictions about the world, as well as our more basic beliefs, values and norms, are held by reasonable and educated people everywhere. ${ }^{60}$

Lewis advocated a 'process of introspective learning' in order to allow the analyst to identify the 'subjective elements of his personal perceptions.' One would thereby build:

a more solid basis for conscious comparison between his own perspectives and those of people of a different culture. Jogging oneself repeatedly to make such conscious comparisons will root a habit of surfacing perceptual differences. In this way an awareness of the unreliability of one's own perspectives on the world and rational for action is strengthened. ${ }^{61}$

Lewis suggested concrete ways in which this might be achieved suggesting for example a 'behavioural learning technique' called "Contrast-American" which had been 'used with most Foreign Service Officers at the Foreign Service Institute since late 1972, and was made available for use in CIA in July 1973.' This involved trainee analysts watching a videotaped series of encounters between Americans and nonAmericans in order 'to identify the single and typical American cultural characteristic which the American in the videotaped encounter manifests in each scene of a sequence.' The aim was 'to recognise the various subtle ways in which their own thought processes, feelings and behaviour are influenced by cultural factors. ${ }^{62}$

Other less systematic ways included the study of language rather than a reliance on translations. Lewis wrote that language 'is both a product and bearer of their culture' and mere translation loses 'the sender's frames of reference - a part of his culture which the receiver does not share. This explains why we must dig hard to grasp what a people's beliefs, values and norms mean to them.' He went on to suggest that 'probing the thought patterns behind the proverbs and aphorisms of a people can be a fascinating and highly productive hobby in the quest for how the mentality of a foreign people differs from ours.' Lewis argued for 'an urgent need for the foreign

\footnotetext{
${ }^{60}$ Anthony Lewis, 'Re-examining our Perceptions on Vietnam' in Studies in Intelligence, Vol. 17, No. 4 (1973), FOIA Reading Room.

${ }^{61}$ Ibid: 'In turn, the motivation becomes stronger to acquire the new jogging habit in order to eradicate old habits of misperception which would otherwise continue to limit one's effectiveness.'

${ }^{6}$ Ibid.
} 
affairs agencies to provide instruction for both intellectual and skill learning for intercultural analysis. ${ }^{63}$

With the unprecedented global challenge to orthodoxies posed by the student protests of the late 1960s, the civil rights movement, the sexual revolution and of course the Vietnam war alongside intellectual developments such as the growth of behavioural sciences, CIA analysis of 'Otherness' had thus evolved to stress a greater focus on the 'Self'. No longer were analysts merely trying to identify the immutable characteristics of the 'Other' but rather question the universality of their own logic and in this more self-conscious way attempt to overcome the analytical challenges of cultural 'Otherness. ${ }^{64}$

\section{NATIVE ORIENTALISM}

A remarkable diplomatic exchange some months earlier between the British ambassador in Jordan, Balfour Paul and Head of the Near East Division, James Craig reveals both the endurance of certain ideas about the Arab world cited above and Arab complicity in perpetuating such ideas. In a remarkable demonstration of selforientalising, Balfour Paul relayed the thesis advanced to him by Zaid Rifai, the Jordanian foreign minister that 'Arabs must be dealt with as children., ${ }^{65}$

Within this framework Rifai reinforced the importance of several factors which had already been raised by the CIA and British foreign office for many years and cited above: the predominant role of the 'personal' interlocutor and 'verbal' as opposed to written agreements in the Arab world, alongside the distinction between 'the real' and 'the declared' in Arab foreign policy. Whilst the archives rarely reveal so lengthy an exposition of cultural self-criticism, this is certainly not an isolated example. 'Orientalist' depictions of the Arab world were often advanced or at least validated by the Arab political elite themselves.

The recipient of the memorandum, diplomat James Craig was quite prepared to endorse Zaid's comments. He wrote, 'one of the most striking characteristics of the

\footnotetext{
${ }^{63}$ Ibid.

${ }^{64}$ It is notable that this was an early precursor to the substantial contemporary literature on different strategic cultures. See for example, J. L. Johnson, and J. A. Larsen, Comparative Strategic Cultures Syllabus, 20 November 2006. http://www.fas.org/irp/agency/dod/dtra/syllabus.pdf [last accessed 30 September 2012]

${ }^{65}$ Memorandum from Balfour Paul in Amman to Craig in FCO, 27 August 1973, TNA, FCO 93/82.
} 
vast majority of Arabs, leaders and led, public and private, is their lack of moral courage. ${ }^{66}$ He reflected also upon the disparity between what the Arabs said and what they mean. 'Have we not all been told by the Arabs in private that they love us but cannot say so in public? Have we not all wondered whether the private whisper or the public statement represented the real sentiment of the heart?' Craig qualified that 'though I don't pretend that the verities Zaid was dealing with are eternal, I suspect they may in the end be more useful in working towards an Arab-Israel settlement than all our talk of interim arrangements and demilitarisation.' He concluded his reply with the assertion that upon retirement he would write of his experiences in a book entitled, 'Arabs and the Arab mentality: a study in frustration. ${ }^{, 67}$

In partial fulfilment of this hope, a presentation to the BRIMSES in 2001 by Sir James Craig confirmed the endurance of some of these ideas about the Arab world. ${ }^{68}$ Echoing Naffsinger's assertion that the Greek philosophy of 'know thyself' was unknown in the Arab world, he claimed that 'the beginning of self-criticism has been a refreshing breeze.' He recalled Algerian President Bourguiba castigating his fellow Arabs for their lack of realism. 'The Arabs remind me' he cited Bourguiba claiming, 'of a man who because he is angry with his wife and wants to punish her, cuts off his penis.' Craig maintained also that 'there is something seriously discouraging in the system of education' in the region resulting in a belief that the 'pursuit of original ideas will be inhibited by the climate of society.' At the same time he dismissed as 'utterly discredited and risible the idea of a genetically different Arab mind., 69

The durability of these ideas and interviews with both British and Egyptian diplomats suggest that there is a relationship between these ideas and the 'real' Arab world. When presented with excerpts from these controversial analyses, several senior Egyptian diplomats agreed with their findings. 'They are right, it is true' said Nasser's daughter, Hoda. ${ }^{70}$ The exception was Hassanein Heikal who dismissed such ideas of cultural difference as merely encouraging division among nations. Recent British ambassador to Egypt, Sir Derek Plumbly expressed 'sympathy' with Heikal's view as

\footnotetext{
${ }^{66}$ Reply from Craig in FCO to Balfour Paul in Amman, 14 September 1973, TNA, FCO 93/82.

${ }^{67}$ Ibid. As an example he cited the Sheikh of Dubai 'who for all his power and pelf could not tell a palace driver he was sacked.'

${ }^{68}$ For a more recent analysis of Arab culture by a prominent British Arabist, see Mark Allen, Arabs (London: Continuum, 2006).

${ }^{69}$ James Craig, 'A life with the Arabs', BRIMSES Annual lecture in British Journal of Middle Eastern Studies, Vol. 28, No. 2 (2001)

${ }^{70}$ Hoda abd el Nasser, interview with the author, Cairo, 2 March 2006.
} 
did other British diplomats understandably uncomfortable with the quasi-racist language of the earlier CIA studies. ${ }^{71}$ Others resolutely differentiated between ignorant cultural stereotypes and 'valid' cultural knowledge and understanding, born of exposure to, and immersion in, the Middle East. ${ }^{72}$ It is striking that for the most part, British diplomats were more critical and defensive about these assumptions than their Arab counterparts. ${ }^{73}$ As one put it, 'Said could justifiably write quod erat demonstratum from the grave. ${ }^{74}$

This article has sought to reconstruct the challenges the British and American political and intelligence community perceived itself to confront in the Middle East, the beliefs and conceptualisations formulated in order to rise to this challenge and the evolution of thought in understanding the Arab 'Other.' It shows that in contrast to accusations of 'failure' to do so, attempts were clearly made to comprehend the 'foreign thought structure' of the Arab world.

By 1959 the political elite on both sides of the Atlantic had made explicit a set of ideas about the 'Otherness' of Arab culture, some of which continue to prevail. Foremost amongst these were the challenge of Arab 'rhetoric', the problems of Arab 'motivation', the influence of Islam and the pre-eminence of 'honour'. Despite many simplistic stereotypes, the practical challenges identified and the relativity of cultural values, were important and valid observations. The British Foreign Office, with greater experience in the region adopted a more sophisticated and analytical, if less self-reflexive approach. Education and history were rightly identified as crucial determinants in explaining the 'cultural Otherness' encountered, rather than an inherent and immutable 'Arab mind.'

In many ways it is true that Western evaluations of 'the Arab' appear repeatedly and explicitly to reassert the moral superiority of the West. At the same time, there are also indications of an evolution of thought about the 'Arab Other.' Compared with the CIA study of 1959 which relied on simplistic cultural observations, the 1964 analysis demonstrated a concerted attempt to understand the different value systems upon

\footnotetext{
${ }^{71}$ Hassanein Heikal, interview with the author, Cairo, 1 March 2006.

${ }^{72}$ James Craig, interview with the author, Oxford, 24 October 2011.

${ }^{73}$ Correspondence with Derek Plumbly, Patrick Wright, Roger Tomkys.

${ }^{74}$ Roger Tomkys, correspondence with the author, September 2012.
} 
which decisions in the Arab world were taken, notably the prevalence of honour or 'face.' Moreover the later 1973 analysis, obviously informed by failures in Vietnam, shifted the focus entirely from an examination of the 'Other' to that of the 'Self'. Thus, alongside continuity in certain beliefs there is also a sense of development in these analyses, a greater self-consciousness and awareness of the complexity of 'culture'. This shift may well have been merely an artefact of growing sophistication at large in thinking about cultures as being more or less superior than one's own - the international version of 'Others' as different but equal, as epitomised in the civil rights movement. The expansion of the U.N. to include a significant majority of decolonised states aptly represented this shift towards multiculturalism and multiracialism on an international scale. Certainly the nuances of analysis detectable are embedded in the wider systems of thought and society at the time. Nonetheless the qualitative development of these assessments clearly disproves Said's contention that 'Orientalism' or the Western gaze upon the Arab world, cannot develop.

At the same time one cannot help but conclude that there is some truth to Said's contention that power relationships have been reified as truths about culture. The legacy of colonisation, and the assumption of Western superiority upon which it relied, is inescapable and permeates the language of these documents. There is certainly a sense that ideas about the Arab national character persisted in the face of independent nationhood in order to prop up the illusion that the Western world was still on top. Perhaps infantilising Arab culture betrayed a denial on the part of analysts of the real relations being played out in the assertion of pan-Arab nationalism. As Said argues, such ideas about the Arab world 'necessarily provokes unrest in one's conscience about cultural, racial or historical generalisations, their uses, value, degree of objectivity and fundamental intent. ${ }^{75}$

Certainly the notion of an immutable, unchanging 'Arab mind' is as deluded and deceptive as the idea of a homogenous static 'Western mind.' Yet to deny that geography, historical experience and social conditions create and reflect cultural differences, variations of systems and meanings in society, and thus differences in values and priorities is also patently illusory. It was certainly more difficult for analysts to recognise that Arab culture, like any other, was a 'repertoire' of ideas, actively constructed and quietly shifting. However, their analysis was constructed in

\footnotetext{
${ }^{75}$ Said, Orientalism, p. 96.
} 
an era where Western superiority was little questioned, and therefore their early attempts at relative thinking is worthy of some credit. Whilst these documents read badly to our twenty-first century ears, there is certainly an argument to be made for the virtues of expressing such cultural beliefs explicitly, and thus allowing them to be subject to debate and criticism, rather than informing (or subverting) analysis implicitly.

The alternative to cultural knowledge, for all its pitfalls, is a more worrying state of a falsified universalism of values, doctrines and beliefs by which all are expected to abide; one dimensional notions of 'democracy,' 'freedom' and 'rationality' spring to mind. The dangers of such universalism and its recent political ramifications in international relations only reinforce the importance of further progress in cultural studies by intelligence communities, despite the contemporary inhibitions of political correctness, limited resources and the ever-increasing speed of communications. The perhaps clumsy beginnings by the Anglo-American intelligence and diplomatic community were to make an important, if controversial, contribution to this end. 